\title{
Maize growth promotion by inoculation with Azospirillum brasilense and metabolites of Rhizobium tropici enriched on lipo-chitooligosaccharides (LCOs)
}

\author{
Bettina Berquó Marks', Manuel Megías², Francisco Javier Ollero², Marco Antonio Nogueira', \\ Ricardo Silva Araujo ${ }^{3}$ and Mariangela Hungria ${ }^{* *}$
}

\begin{abstract}
There is an increasing interest in the development and use of inoculants carrying plant growth-promoting bacteria (PGPB) in crops of agronomic interest. The great majority of the inoculants commercialized worldwide contain rhizobia for legume crops, but the use of PGPB as Azospirillum spp. for non-legume is expanding, as well as of inoculants combining microorganisms and microbial metabolites. In this study we evaluated the effects of inoculants containing Azospirillum brasilense with or without metabolites of Rhizobium tropici strain CIAT 899 highly enriched in lipo-chitooligosaccharides (LCOS) in six field experiments performed for three summer crop seasons in Brazil with maize (Zea mays L.). Inoculants and metabolites were applied either at sowing by seed inoculation, or by leaf spray at the V3 stage of plant growth. Improvement in shoot dry weight (SDW) and total N accumulated in shoots (TNS) by single, but especially by dual inoculation was observed in some of the experiments. Statistically significant increases in grain yield in relation to the non-inoculated control were observed in five out of six experiments when maize was inoculated with Azospirillum supplied with enriched metabolites of $R$. tropici applied by seed or leaf spray inoculation. The results give strength to the development of a new generation of inoculants carrying microorganisms and microbial molecules.
\end{abstract}

Keywords: Nod factor, Zea mays, Inoculant, PGPB

\section{Introduction}

Inoculation of crops of agronomic interest with plant growth-promoting bacteria (PGPB)-especially those belonging to the group of rhizobia associated with legumes-represents a biotechnological practice consolidated worldwide (Bashan et al. 2014). In Brazil, for example, about 25 million doses of inoculants are commercialized every year, $95 \%$ of which for the soybean (Glycine max [L.] Merr.) crop (Hungria and Mendes 2015).

The symbiotic interaction between rhizobia and the host legumes to establish the biological nitrogen fixation

\footnotetext{
*Correspondence: mariangela.hungria@embrapa.br; biotecnologia.solo@ hotmail.com; hungria@cnpq.br

1 Embrapa Soja, C.P. 231, Londrina, Paraná 86001-970, Brazil

Full list of author information is available at the end of the article
}

process involves an intense exchange of signals between the partners. The dialogue starts with the exudation of molecules by the plant-especially flavonoids - which act as signals to the rhizobia (Hungria et al. 1992; Hungria and Phillips 1993; de Rijke et al. 2006). The interaction occurs by means of a key protein in rhizobia-NodDlaunching the expression of all other bacterial nodulation genes; in the following step, rhizobia reply with the synthesis and secretion of Nod Factors (Phillips 2000). Nod Factors are lipo-chitooligosaccharides (LCOs), which may comprise up to 60 different structural arrangements (D'Haeze and Holsters 2002), depending on the bacterial species and the environmental conditions (Folch-Mallol et al. 1996; Debellé et al. 2003; Estévez et al. 2009; del Cerro et al. 2015a, b). LCOs act directly in root colonization and cortex cell division (Spaink et al. 1998; Dardanelli et al. 2008).

\section{望 Springer}


Intriguingly, it has been reported that LCOs can also promote growth of non-leguminous plants, one possible explanation being because they mimic the effects of plant hormones such as cytokinins and auxins (Rélic et al. 1993), resulting in increased seed germination and resistance to pathogens (Miransari and Smith 2009). With the current knowledge about the effects of LCOs, a new generation of inoculants based on, or enriched with LCOs has proven to be very effective with legumes, and is now advancing to the use with non-legumes (Marks et al. 2013; Smith et al. 2015).

The technology of inoculation of non-legumes with non-symbiotic PGPB-whose main representative is Azospirillum spp.--is also being increasingly adopted in several countries, especially for crops such as maize (Zea mays L.) and wheat (Triticum aestivum L.) (DíazZorita and Fernandez-Canigia 2009; Hartmann and Bashan 2009; Smith et al. 2015). In Brazil, inoculants containing Azospirillum brasilense strains Ab-V5 and Ab-V6 were exponentially employed by farmers in the past 5 years for maize and wheat (Hungria et al. 2010; Hungria 2011). More recently, co-inoculation of soybean with rhizobia and azospirilla has also been adopted as an agronomic practice by several farmers, with reported positive effects on nodulation precocity (Chibeba et al. 2015) and increases in grain yield (Hungria et al. 2013, 2015b); positive effects on common bean (Phaseolus vulgaris L.) yield have also been reported (Hungria et al. 2013). Among the benefits of inoculation with non-symbiotic PGPB, the contributions of biological nitrogen fixation (Ashraf et al. 2011), production of phytohormones (Strzelczyk et al. 1994), phosphate solubilization (Rodriguez et al. 2004) and control of plant pathogens (Araujo et al. 2005; Wang et al. 2009) are commonly cited.

Studies of the application of LCOs associated with Azospirillum to cereals crops are still incipient. Our research group has previously reported that the addition of concentrated metabolites (CM) from two strains of rhizobia containing LCOs resulted in significant increases in maize grain yield (Marks et al. 2013). Rhizobium tropici is a very interesting species that synthesizes a wide variety of LCOs, even in the absence of plant inducers (Estévez et al. 2009; del Cerro et al. 2015a, b), making it an interesting bacterium for metabolite production. In this study, metabolites of $R$. tropici strain CIAT 899 highly enriched in LCOs were obtained and applied along with $A$. brasilense in six field experiments performed in 3 years, aiming at getting a better understanding of the combined effects Azospirillum and rhizobial molecules on the growth and yield of cereals.

\section{Materials and methods Inoculant and lipo-chitooligosaccharides (LCOs) preparation}

Liquid inoculants were prepared with $A$. brasilense strains CNPSo 2083 (=Ab-V5) and CNPSo 2084 (=AbV6). Strains are deposited in the Diazotrophic and Plant Growth Promoting Bacteria Culture Collection of Embrapa Soja (WFCC Collection \#1213, WDCM Collection \#1054). These two elite strains were identified in a previous selection program for the maize and wheat crops (Hungria et al. 2010; Hungria 2011) and are used in commercial inoculants in Brazil. Inoculant concentration was determined by spread-plating on NFb (Hungria and Araujo 1994; Döbereiner et al. 1995) and RC (Cassán et al. 2010) solid media and adjusted to the concentration of $2 \times 10^{8} \mathrm{CFU}$ (colony forming units) $\mathrm{mL}^{-1}$ in all three crop seasons.

Metabolites of $R$. tropici strain CIAT 899 enriched in LCOs were produced with a combination of procedures. Bacterium growth and extraction of the supernatant $n$-butanol were performed as described by Sanjuan et al. (1992). Purification was accomplished by solidphase chromatography, with SPE C18 Resprep, Teknokroma column, concentration and lyophilization were performed as described by Soria-Díaz et al. (2003) and Guasch-Vidal (2011). Prior to sowing, lyophilized metabolites of $R$. tropici CIAT 899 were re-suspended in a mixture of acetonitrile and water (20\%). The concentration was adjusted to $0.1 \mathrm{~mL} \mathrm{~L}^{-1}$, corresponding to approximately $10^{-9} \mathrm{M}$. The metabolites were added to the inoculant containing Azospirillum at the time of inoculation, either when applied to the seeds, or by spraying.

\section{Field experiments}

Sites description

Six field experiments were conducted over a 3-year period, always in the summer crop season. Two experiments were conducted in 2012/2013, in Ponta Grossa, State of Paraná (southern region) and Cachoeira Dourada, State of Goiás (central-western region), two others in 2013/2014, in Rio Verde, State of Goiás (central-western region), and Maracaí, State of São Paulo (southeastern region), and two others in the crop season of 2014/2015, in Londrina, State of Paraná (southern region) and Ponta Grossa.

Ponta Grossa $\left(25^{\circ} 13^{\prime} \mathrm{S}, 50^{\circ} 1^{\prime} \mathrm{W}\right)$ is at $880 \mathrm{~m}$ of altitude and has a Köppen-Geiger climate type $C f b$ (temperate with mild summer). Cachoeira Dourada $\left(18^{\circ} 29^{\prime} \mathrm{S}\right.$; $\left.49^{\circ} 28^{\prime} \mathrm{W}\right)$ is at $450 \mathrm{~m}$ of altitude and has a climate type $A w$ (tropical with dry season in the winter). Rio Verde $\left(17^{\circ} 47^{\prime} \mathrm{S} ; 50^{\circ} 54^{\prime} \mathrm{W}\right)$ is at $730 \mathrm{~m}$ altitude and has a climate type $A w$, Maracaí $\left(22^{\circ} 36^{\prime} \mathrm{S} ; 50^{\circ} 40^{\prime} \mathrm{O}\right)$ is at $475 \mathrm{~m}$ and has a climate type $C f a$ (tropical humid with warm summer) 
and Londrina $\left(23^{\circ} 11^{\prime} \mathrm{S}, 51^{\circ} 11^{\prime} \mathrm{W}\right)$ is at $620 \mathrm{~m}$ altitude and has a climate type $C f a$. The trials were performed on soils classified as Latossolo Vermelho Distrófico (Brazilian classification) (Typic Hapludox, USA Soil Taxonomy) (Ponta Grossa, Cachoeira Dourada, Rio Verde, Maracaí), and Latossolo Vermelho Eutroférrico (Brazilian classification) (Rhodic Eutrudox, USA Soil Taxonomy) in Londrina.

At each site, 2 months before the experiments were established twenty soil samples $(0-20 \mathrm{~cm}$ depth) were taken to evaluate chemical properties, granulometry and biological properties. For chemical analyses, the samples were previously dried $\left(60^{\circ} \mathrm{C}\right.$ for $\left.48 \mathrm{~h}\right)$, sieved $(2 \mathrm{~mm})$, and analyzed as described before; soil granulometry was also analyzed as described before (Hungria et al. 2010; Hungria et al. 2015a). Population of free-living diazotrophic bacteria was estimated by the NMP method with dilutions in NFb semi-solid medium (Hungria and Araujo 1994; Döbereiner et al. 1995). Soil properties are shown in Table 1.

About 50 days before starting the experiment, lime was applied to alleviate acidity when necessary, based on soil $\mathrm{pH}$ values. The amount of lime applied was estimated for a base saturation of $50 \%$, to increase the $\mathrm{pH}$ to 5.5 or higher.

\section{Treatments, experimental design and field management}

The maize hybrids used in the experiments were DOW 2B 707 HX (Dow AgroSciences) in 2012/2013, DKB-350-PRÓ (Dekalb) in 2013/2014, and DKB-350PRÓ2 (Dekalb) in 2014/2015. Seeds were not surface disinfected.

Two methods for the inoculation with $A$. brasilense strains CNPSo 2083 and CNPSo 2084 were tested. The first method consisted of seed inoculation at sowing and the second of leaf spray with the same inoculant at the V3 stage (third leave developed).

The experiments consisted of five treatments: (1) noninoculated control (NI); (2) seed inoculation (SI) with Azospirillum at sowing; (3) SI + metabolites enriched with LCOs applied at sowing; (4) leaf spray inoculation (LSI) with Azospirillum strains at V3 stage; (5) LSI + enriched metabolites at the V3 stage.

Seed inoculation was performed at a rate of $100 \mathrm{~mL}$ $20 \mathrm{~kg}^{-1}$ of seeds $\left(2 \times 10^{8} \mathrm{CFU} \mathrm{mL}{ }^{-1}\right)$ while the spray inoculation was applied at a rate of $200 \mathrm{~mL} \mathrm{ha}^{-1}\left(2 \times 10^{8}\right.$ $\mathrm{CFU} \mathrm{mL} \mathrm{L}^{-1}$ ) diluted in $100 \mathrm{~L}$ of water; $20 \mathrm{~kg}$ of seeds give rise to a population of about 60,000 plants $^{-1}$. Enriched metabolites were prepared at a concentration of $0.1 \mathrm{~mL}$ $\mathrm{L}^{-1}$ and mixed with the inoculant before application at a rate of $50 \mathrm{~mL} 20 \mathrm{~kg}^{-1}$ of seeds when applied to the seeds and of $100 \mathrm{~mL} \mathrm{ha}^{-1}$ when sprayed.

As mentioned above, the main objective of our study was to verify the plant growth-promoting activity of the enriched bacterial metabolites. Therefore, all treatments received the same fertilization, consisting of $300 \mathrm{~kg} \mathrm{ha}^{-1}$ of a formulation of 08-20-20 (corresponding to $24 \mathrm{~kg}$ of $\mathrm{N}, 60 \mathrm{~kg}$ of $\mathrm{P}$ and $60 \mathrm{~kg}$ of $\mathrm{K} \mathrm{ha}^{-1}$ ) at sowing and a topdressing fertilization at the V4 stage (four fully developed leaves), representing $75 \%$ of the usual dose of $\mathrm{N}$-fertilizer recommended for the crop in Brazil, corresponding to $90 \mathrm{~kg} \mathrm{~N} h a^{-1}$ of urea $\left(67.5 \mathrm{~kg} \mathrm{~N} \mathrm{ha}^{-1}\right)$.

Plots measured $4.5 \mathrm{~m}$ (width) $\times 8 \mathrm{~m}$ (length) $\left(=27 \mathrm{~m}^{2}\right)$, with rows spaced by $0.9 \mathrm{~m}$ and plots were separated by $2 \mathrm{~m}$ terraces to prevent contamination by superficial runoff containing bacteria, metabolites or fertilizers. The experiments were set in a complete randomized block design with six replicates.

Cultural and phytosanitary managements followed the technical recommendations for the maize crop (Embrapa 2011). The experiments were not irrigated.

\section{Plant sampling, harvesting and analyses}

Between 29 and 57 days after sowing (DAS), depending on the climatic conditions, five plants were randomly collected from each plot to evaluate the performance at the vegetative growth. Shoots were washed and dried to constant weight at $50{ }^{\circ} \mathrm{C}$ for evaluation of shoot dry weight (SDW). Shoots were then ground (20 mesh) and total N was determined by sulfuric digestion followed by semimicro Kjeldahl distillation method, as described before (Hungria et al. 2015a).

At the time of physiological maturity, plant height (PH) was determined based on the average of six plants, and plant population was also estimated. Grain yields $\left(\mathrm{kg} \mathrm{ha}^{-1}\right)$ were determined by harvesting a $6.3 \mathrm{~m}^{2}$ area ( $0.9 \mathrm{~m}$ wide $\times 7 \mathrm{~m}$ long) from the central portion of each plot. Grains were cleaned and weighed, the humidity evaluated in a grain moisture tester and the content corrected to $13 \%$ moisture. In 2013/2014 and 2014/2015 the $\mathrm{N}$ content of seeds was also determined, as described for shoots.

It is worth mentioning that all field experiments were performed according to the Brazilian legislation required for the registration of commercial inoculants or technologies of inoculation for plant growth-promoting bacteria (MAPA 2011).

\section{Statistical analyses}

Data from each experiment were first submitted to tests of normality and homogeneity of variances for each variable and then to the analysis of variance (ANOVA). When significant differences were detected by the $\mathrm{F}$ test, Duncan's multiple-range test at $p \leq 0.05$ and 0.10 (for inoculant products the Brazilian legislation accepts $p \leq 0.10$; MAPA 2011) was used as a multiple comparisons procedure. 


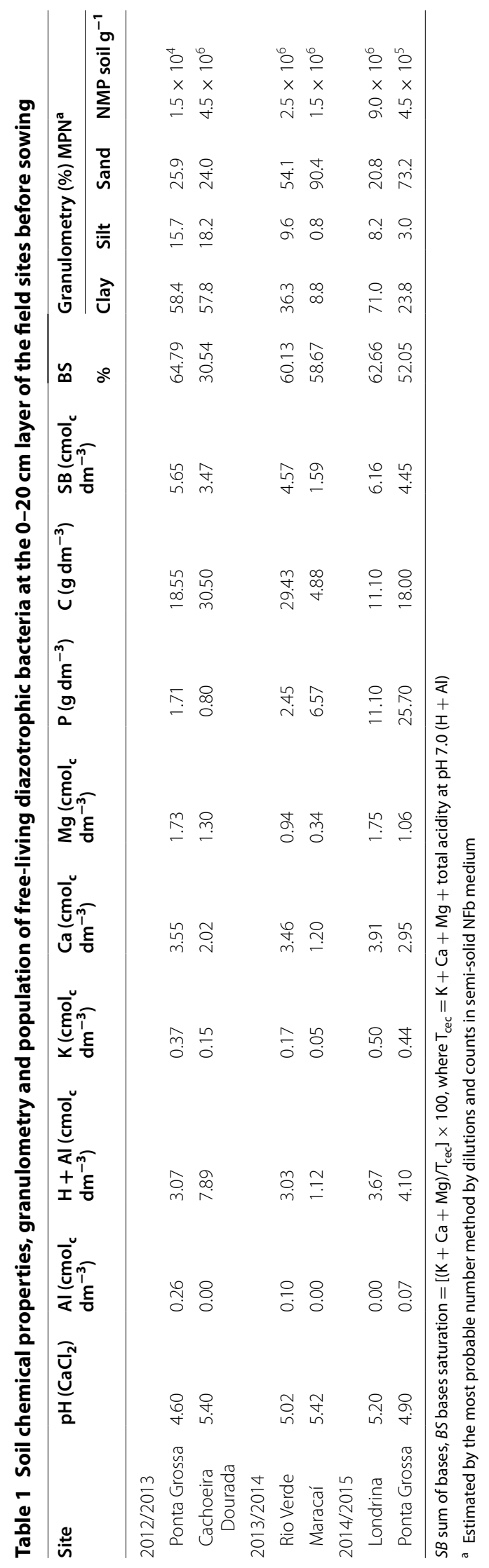




\section{Results}

In the 2012/2013 crop season, in Ponta Grossa, grain yield of maize plants inoculated with $A$. brasilense and supplied with enriched metabolites either at sowing or at the V3 stage was significantly higher than the other treatments (Table 2). In Cachoeira Dourada, shoot dry weight (SDW) and total $\mathrm{N}$ accumulated in shoots (TNS) were significantly increased when Azospirillum was inoculated on the seeds (Table 2). The supplementation with enriched metabolites associated to seed inoculation with Azospirillum seemed to improve the same parameters at this site, even though this treatment did not show significantly higher SDW than the other treatments (Table 2). In addition, in Cachoeira Dourada both treatments with Azospirillum inoculated on seeds along with enriched metabolites, and Azospirillum-inoculated by leaf spray added of enriched metabolites promoted higher yield than the other treatments (Table 2).

In 2013/2014, in Rio Verde, the supplementation of both treatments that received Azospirillum inoculation, either on seeds or by leaf spray, with enriched metabolites resulted in significant increases in the $\mathrm{N}$ content of the grains (TNG, Table 3). In Maracaí, the best performance was achieved again in the treatment pulverized with $A$. brasilense supplied with enriched metabolites, resulting in greater yield, values of accumulation of $\mathrm{N}$ in grains (NG) and TNG, in general statistically higher than all other treatments (Table 3 ).
In Londrina, in 2014/2015, leaf spray with Azospirillum resulted in significant increases in SDW relative to the non-inoculated controls, either in the presence or in absence of enriched metabolites (Table 4). Seed inoculation resulted in increased grain yield relative to the non-inoculated control, but no further increases were observed when metabolites were added; in contrast, leaf spray inoculation only resulted in yield increases when supplemented with enriched metabolites (Table 4). In Ponta Grossa, the addition of the enriched metabolites to both inoculation with Azospirillum by seeds or leaf spray resulted in increased grain yield when compared to the non-inoculated control and to the treatments inoculated only with Azospirillum (Table 4).

\section{Discussion}

One of the main goals of new biotechnological products is to reduce the agricultural utilization of pesticides and/or chemical fertilizers, providing higher sustainability associated with enhanced environmental quality (Hameeda et al. 2006). In this study, we observed that when maize seeds were inoculated with $A$. brasilense strains CNPSo 2083 and CNPSo 2084, there were no increases in grain yield in the leaf spray treatment. When Azospirillum was applied on seeds, statistically significant increases were observed in two out of six experiments. Although this percentage is lower than usually reported (Okon and Labandera-Gonzalez 1994; Díaz-Zorita and

Table 2 Effect of Azospirillum brasilense strains CNPSo 2083 and CNPSo 2084 and of enriched metabolites of R. tropici strain CIAT 899 applied to the seeds at sowing or by leaf spray at the V3 stage on plant growth (shoot dry weight, SDW; plant height, PH), shoot N (content [NS] and total N accumulated in shoots [TNS]) at 57 and 51 days after sowing (DAS), and grain (yield) at the physiological maturity of maize hybrid DOW 2B $707 \mathrm{HX}$

\begin{tabular}{|c|c|c|c|c|c|c|c|c|c|c|}
\hline \multirow[t]{3}{*}{ Treatment } & \multicolumn{5}{|l|}{ Ponta Grossa } & \multicolumn{5}{|c|}{ Cachoeira Dourada } \\
\hline & \multicolumn{4}{|l|}{57 DAS } & \multirow{2}{*}{$\begin{array}{l}\text { Maturity } \\
\text { Yield } \\
\left(\mathrm{kg} \mathrm{ha}^{-1}\right)\end{array}$} & \multicolumn{4}{|l|}{51 DAS } & \multirow{2}{*}{$\begin{array}{l}\text { Maturity } \\
\text { Yield } \\
\left(\mathrm{kg} \mathrm{ha}^{-1}\right)\end{array}$} \\
\hline & $\mathrm{SDW}\left(\mathrm{g} \mathrm{pl}^{-1}\right)$ & $\mathrm{PH}(\mathrm{cm})$ & NS $\left(\mathrm{g} \mathrm{kg}^{-1}\right)$ & $\begin{array}{l}\text { TNS (mgN } \\
\left.\mathrm{pl}^{-1}\right)\end{array}$ & & $\operatorname{SDW}\left(\mathrm{g} \mathrm{pl}^{-1}\right)$ & $\mathrm{PH}(\mathrm{cm})$ & $N\left(g_{k g}^{-1}\right)$ & $\begin{array}{l}\text { TNS (mgN } \\
\left.\mathrm{pl}^{-1}\right)\end{array}$ & \\
\hline $\begin{array}{l}\text { Non-inoculated } \\
\text { control }\end{array}$ & $56.1^{\mathrm{ns}}$ & $252^{\mathrm{ns}}$ & $23.04^{\text {ns }}$ & $1292^{\text {ns }}$ & $8406 b$ & $33.1 \mathrm{C}$ & $234^{\mathrm{ns}}$ & $21.16^{\mathrm{ns}}$ & $700 \mathrm{~b}$ & $6310 b$ \\
\hline $\begin{array}{l}\text { Seed inoculated } \\
\text { (Azospirillum) }\end{array}$ & 58.3 & 260 & 23.86 & 1391 & $8850 b$ & $44.1 \mathrm{a}$ & 242 & 21.00 & $926 \mathrm{a}$ & $6567 b$ \\
\hline $\begin{array}{l}\text { Seed inoculated } \\
\text { (Azospiril- } \\
\text { lum + enriched } \\
\text { metabolites) }\end{array}$ & 52.7 & 253 & 22.64 & 1193 & 9225 a & $40.8 \mathrm{ab}$ & 243 & 21.94 & 895 a & 7373 a \\
\hline $\begin{array}{l}\text { Leaf spray inocula- } \\
\text { tion (Azospirillum) }\end{array}$ & 55.0 & 258 & 22.45 & 1235 & $8567 b$ & $36.9 \mathrm{bc}$ & 241 & 21.10 & $779 b$ & $6543 b$ \\
\hline $\begin{array}{l}\text { Leaf spray inocula- } \\
\text { tion (Azospiril- } \\
\text { lum + enriched } \\
\text { metabolites) }\end{array}$ & 55.2 & 256 & 22.71 & 1254 & 9256 a & $36.4 \mathrm{bc}$ & 238 & 21.06 & $766 b$ & 7286 a \\
\hline
\end{tabular}

Field experiments performed in Ponta Grossa and Cachoeira Dourada, Brazil, in the summer crop season of 2012/2013. Means ( $\mathrm{n}=6$ ) on the same column which are followed by different letters are significantly different ( $p \leq 0.10$, Duncan test)

n.s. statistically non-significant 


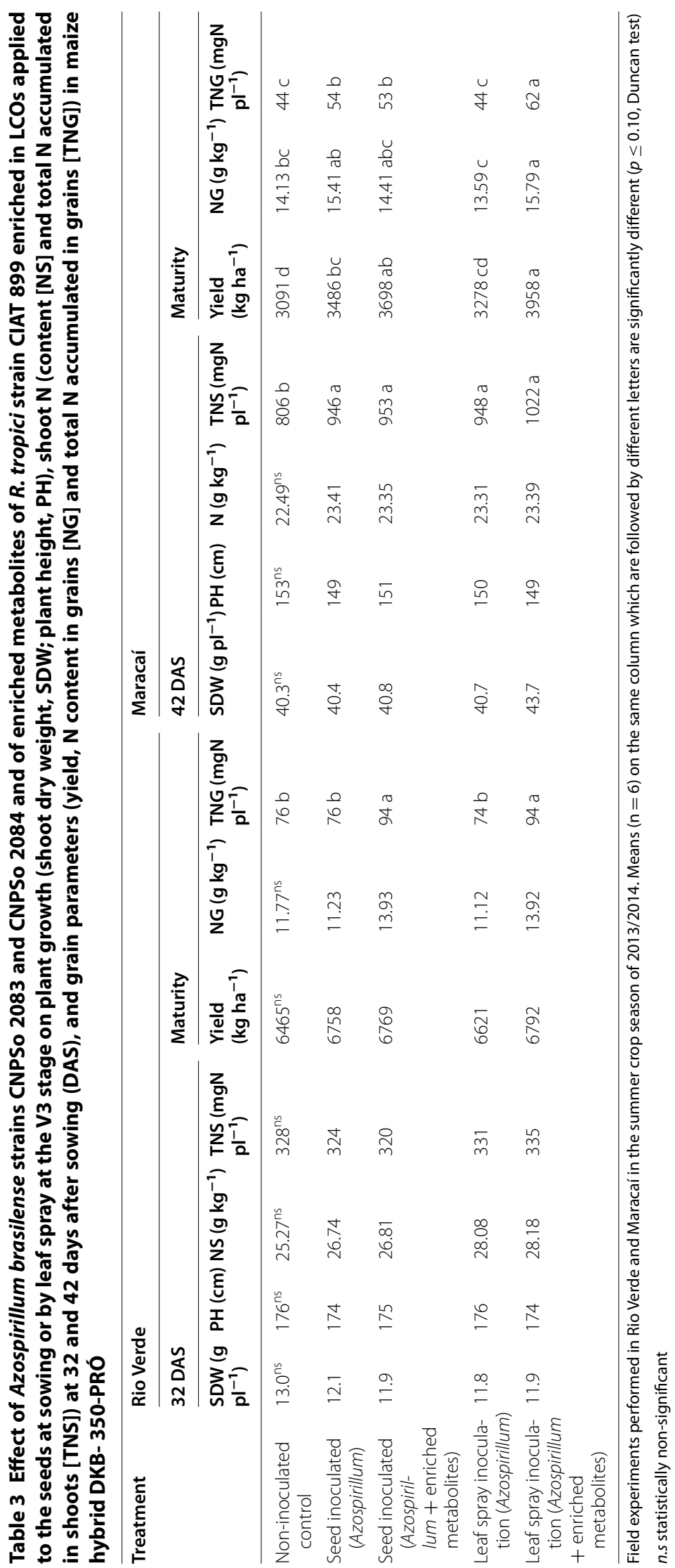




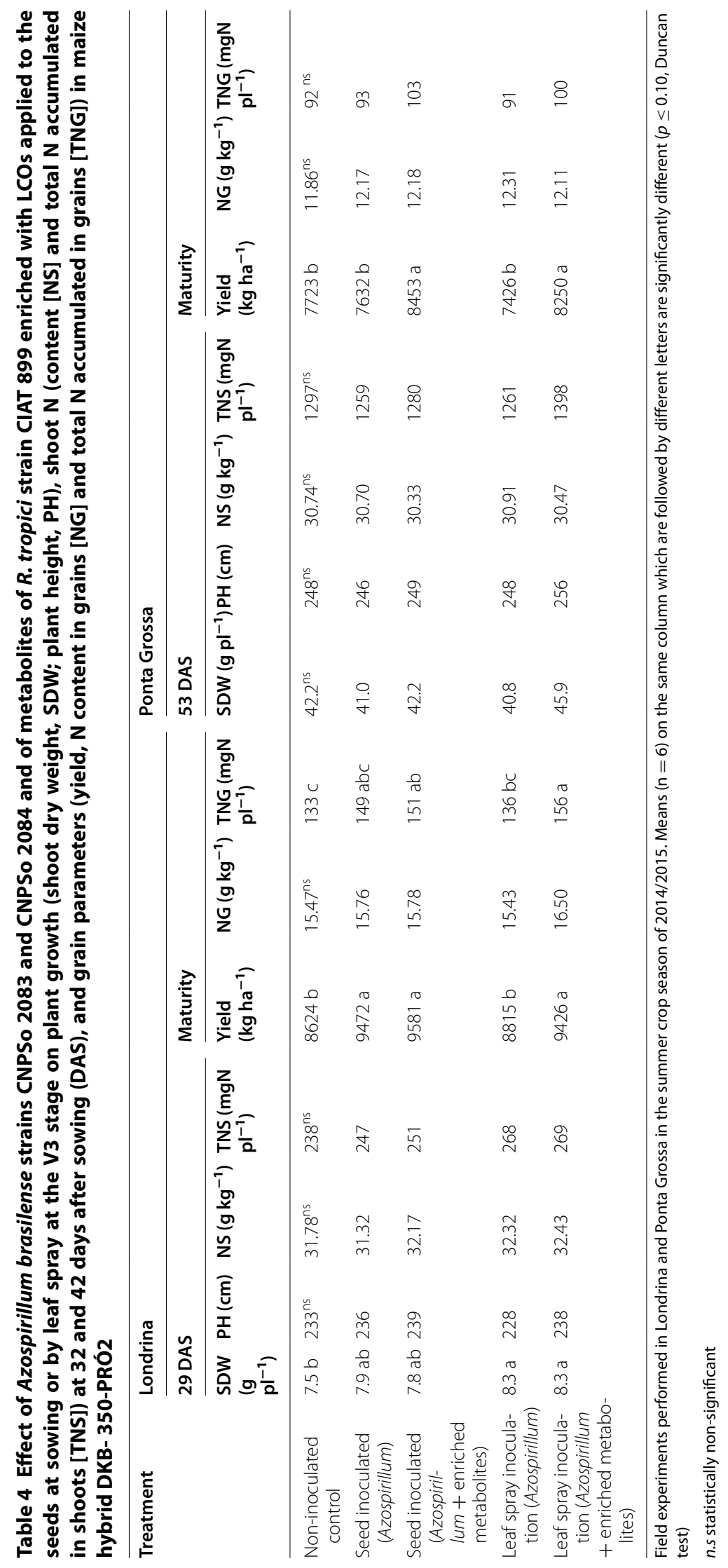


Fernandez-Canigia 2009; Hungria et al. 2010), increments in yield were observed in all trials, and when a combined analysis was performed, there was a statistically significant gain of $358 \mathrm{~kg} \mathrm{ha}^{-1}$ in relation to the non-inoculated treatment. However, when the Azospirillum inoculant was supplemented with LCO-enriched metabolites from $R$. tropici strain CIAT 899, either by seed inoculation or by leaf spray, statistically significant increases in grain yield in comparison to the non-inoculated control were observed in five out of six field experiments, and when compared to the single inoculation with Azospirillum, in three and five out of six experiments for seeds and leaf spray, respectively.

The beneficial relationships between PGPB such as Azospirillum, and several plant species have been previously described (Okon, and Labandera-Gonzalez 1994; Bashan and de Bashan 2010; Cassán et al. 2013). Field experiments have shown increases in grain yield ranging from 5 to 75 \% (Okon and Labandera-Gonzalez 1994; Fuentes-Ramirez and Caballero-Mellado 2005; CastroSowinski et al. 2007; Rodrigues et al. 2008; Hungria et al. 2010). These increases are commonly attributed to root growth promotion, accomplished by phytohormones produced by the bacterium, with an emphasis on indole acetic acid, gibberellins and cytokinins (Tien et al. 1979). Moreover, it is inferred that the application of Azospirillum is also responsible for higher rates of absorption of water and minerals by the plant (Okon, and Kapulnik 1986; Dardanelli et al. 2008) and higher tolerance to abiotic stresses, such as drought and salinity (Cassán et al. 2009; Zawonski et al. 2011).

The relationship between different soil microorganisms and the role of metabolites secreted by them on growth of other surrounding microbial species and plants has been the subject of numerous studies. For example, Massoud et al. (2009) studied the effects of the combined inoculation of mycorrhizal fungi, Bacillus circulans, Rhizobium sp., Azospirillum lipoferum, Azotobacter chroococcum and mineral rocks on common bean (Phaseolus vulgaris L.) plants. The inoculum consortium promoted higher nitrogenase activity and increased the availability of macronutrients, besides promoting plant growth, resulting in increased yield in comparison to the single inoculation (Massoud et al. 2009). The authors attributed these results at least partially to the exudation of beneficial molecules by the microorganisms (Massoud et al. 2009). The positive effects of molecules such as LCOs, exopolysaccharides (EPSs), and plant hormones on plant growth (hosts or non-hosts) may be associated with increased survival and capacity of plant infection by beneficial rhizospheric bacteria and fungi and/or with plant growth promotion (Marks et al. 2013). In a study with the legume model Medicago truncatula, application of LCOs of Sinorhizobium meliloti facilitated root infection by mycorrhizal fungi and stimulated lateral root hair development (Olah et al. 2005). It is possible that LCOs, although produced by rhizobia, have a direct influence on the rhizospheric microbial community by influencing interactions among microorganisms and promoting plant growth, including growth of non-host plants.

The LCOs secreted by rhizobia are described as responsible for several physiological modifications in the root hairs of legumes. Such changes include alterations in ion flux, membrane depolarization of root cells, intra and extracellular alkalization, synthesis of phosphatidic acid and diacylglycerol, accumulation of reactive oxygen species, root hair deformations involving changes in actin cytoskeleton, cell division activation and induction of the expression of genes involved in nodulation (Mulder et al. 2006; Cooper 2007). All these changes allow the rhizobia to invade the host plant, leading to the formation of nodule primordia (Riely et al. 2004), and therefore, LCOs would behave as mitogenic and morphogenic agents (Rélic et al. 1993). However, intriguingly, LCOs have also been described as growth regulators of a wide variety of non-leguminous plants (Prithiviraj et al. 2003), inducing various physiological responses (Souleimanov et al. 2002), as increased seed germination, lateral root development and nutrient uptake (Smith et al. 2015). The study by Rélic et al. (1993) supports the hypothesis that the LCOs may act as plant hormones when applied to non-host plants. Previous studies with cells and plants of tobacco (Nicotiana sp.) (Baier et al. 1999), tomato (Solanum lycopersicum L.) (Staehelin et al. 1994) and carrot (Dacus carota L.) (De Jong et al. 1993) have shown that LCOs are activators of cell division and embryonic development of non-host plants.

Marks et al. (2013) observed, in previous field experiments, an $11.4 \%$ increase in the grain yield of maize inoculated with the same strains of $A$. brasilense and supplied with concentrated metabolites of $R$. tropici that included LCOs. Although the mechanisms responsible for the benefits of LCOs in non-leguminous are not fully understood, the application of such molecules must somehow modify the hormone balance, affecting plant growth and development (Souleimanov et al. 2002). The most effective contribution of LCOs to non-leguminous plants might be the stimulation of root development, increasing the absorption of water and nutrients and resulting in improved plant growth and yields (Smith et al. 2015). In the field experiments performed in our study, the application of LCOs-rich rhizobial metabolites seems to have affected the $\mathrm{N}$ metabolism, increasing the $\mathrm{N}$ content of shoots and grains, and also influencing grain yield.

Our results have also shown that the application of LCOs-rich rhizobial metabolites by leaf spray resulted 
in higher grain yields. Khan (2003) also observed that the leaf application of LCOs in maize stimulated photosynthesis, increased leaf area and shoot dry weight. In another study, Chen et al. (2006) applied LCOs of Bradyrhizobium japonicum to tomato leaves and observed the anticipation of flowering and fruiting and an increase in the number and weight of fruits under greenhouse conditions, as well as a $30 \%$ increase in the number and fruit weight in a field experiment. The benefits of LCOs leaf spray can be attributed to the fact that these molecules indirectly affect the photosynthesis and accelerate growth, probably by the stimulation of mitotic activity in meristematic tissue of leaves (Khan et al. 2008). It can also be inferred that the foliar application of LCOs promotes the suppression of innate immune responses, which possibly facilitates the microbial interactions, such as the invasion and colonization by endophytic bacteria (Liang et al. 2013).

The rationale of the utilization of metabolites of $R$. tropici CIAT 899 enriched on LCOs was based on some interesting properties of this strain, which produces a broad variety of LCOs, even in the absence of inducing flavonoids, when subjected to abiotic stresses such as acidity (Morón et al. 2005) and salinity (Estévez et al. 2009; del Cerro et al. 2015a, b). R. tropici carries five copies of nod gene (Ormeño-Orrillo et al. 2012) and, recently, the synthesis of several LCOs structures related to nodD1, nodD2, nodD3, nodD4 and nodD5 genes has been elucidated (del Cerro et al. 2015a, b). The production of a large variety of LCOs by $R$. tropici CIAT 899 may represent a strategy for nodulation of several host plants under various environmental stressful conditions (Liang et al. 2013; del Cerro et al. 2015a, b). Consequently, it is possible that these LCOs also favor the systemic resistance, particularly in leaf spray, giving greater vigor to the plants, and resulting in increases in crops yields. Therefore, it is likely that LCOs have a broad spectrum of action in regulating plant growth, in addition to its primary function in nodulation of legumes.

The results of our study reveal the biotechnological potential of adding microbial metabolites, in our case rhizobial metabolites enriched with LCOs to products for leaf spray and seed inoculation of non-leguminous plants, such as maize. This knowledge can be applied to the improvement of commercial products, taking into account the need for developing a new generation of inoculants carrying microorganisms and microbial metabolites.

\section{Authors' contributions}

Idealized the experiments: MH, MM, FJO, MAN. Performed the experiments: MH, MAN. Analyzed the data: BBM, MM, FJO, MAN, RSA, MH. Wrote the manuscript: BBM, MH, RSA. All authors read and approved the final manuscript.

\section{Author details}

${ }^{1}$ Embrapa Soja, C.P. 231, Londrina, Paraná 86001-970, Brazil. ${ }^{2}$ Depto de Microbiología, Facultad de Biología, Universidad de Sevilla, Avda. Reina Mercedes 6, Apdo Postal 41012 Seville, Spain. ${ }^{3}$ Total Biotecnologia Indústria e Comércio S/A, Rua Emílio Romani 1190, CIC, Curitiba, Paraná 81460-020, Brazil.

\section{Acknowledgements}

This study was partially supported by Embrapa (02.13.08.001.00.00), Total Biotecnologia Indústria \& Comércio S/A and CNPq (National Council for Scientific and Technological Development, Project Science without Borders \# 400205/2012-5). B.B. Marks acknowledges a PhD fellowship from CAPES (Coordenação de Aperfeiçoamento de Pessoal de Nível Superior, Brazil). M. Hungria and M.A. Nogueira are also research fellows from CNPq. Approved for publication by the Editorial Board of Embrapa Soja as manuscript 285/2015.

\section{Competing interests}

The authors declare that they have no competing interests.

Received: 16 September 2015 Accepted: 17 October 2015

Published online: 14 November 2015

\section{References}

Araujo FF, Henning AA, Hungria M (2005) Phytohormones and antibiotics produced by Bacillus subtilis and their effects on seed pathogenic fungi and on soybean root development. World J Microbiol Biotechnol 21:1637-1642

Ashraf MA, Rasool M, Mirza MS (2011) Nitrogen fixation and indole acetic acid production potential of bacteria isolated from rhizosphere of sugarcane (Saccharum officinarum L.). Adv Biol Res 5:348-355

Baier R, Schiene K, Kohring B, Flaschel E, Niehaus K (1999) Alfafa and tobacco cells react differentially to chitin oligo-saccharides and Sinorhizobium meliloti nodulation factors. Planta 210:157-164

Bashan Y, de Bashan LE (2010) How the plant growth-promoting bacterium Azospirillum promotes plant growth—a critical assessment. Adv Agron 108:77-136

Bashan Y, de-Bashan LE, Prabhu SR, Hernandez J (2014) Advances in plant growth-promoting bacterial inoculant technology: formulations and practical perspectives (1998-2013). Plant Soil 378:1-33

Cassán F, Maiale S, Masciarelli O, Vidal A, Luna V, Ruiz O (2009) Cadaverine production by Azospirillum brasilense and its possible role in plant growth promotion and osmotic stress mitigation. Eur J Soil Biol 45:12-19

Cassán F, Penna C, Creus C, Radovancich D, Monteleleone E, Salamone IG, Di Salvo L, Mentel I, García J, Pasarello MCM, Lett L, Puente M, Correa O, Punschke VK, Massa R, Roosi A, Díaz M, Catafesta M, Righes S, Carletti S, Cáceres ER (2010) Protocolo para el control de calidad de inoculantes que contienen Azospirillum sp. Associación Argentina de Microbiología, Buenos Aires. (Documento de Procedimientos de la REDCAI, 2. ISBN 978-987-98475-9-6)

Cassán F, Vanderleyden J, Spaepen S (2013) Physiological and agronomical aspects of phytohormone production by model plant-growth-promoting rhizobacteria (PGPR) belonging to the genus Azospirillum. J Plant Growth Regul 33:440-459

Castro-Sowinski S, Herschkovitz Y, Okon Y, Jurkevitch E (2007) Effects of inoculation with plant growth-promoting rhizobacteria on resident rhizosphere microorganisms. FEMS Microbiol Lett 276:1-11

Chen C, Mclver J, Yang Y, Bai Y, Schultz B, Mclver A (2006) Foliar application of lipo-chitooligosaccharides (Nod Factors) to tomato (Lycopersicon esculentum) enhances flowering and fruit production. Can J Plant Sci 87:365-372

Chibeba AM, Guimarães MF, Brito OR, Araujo RS, Nogueira MA, Hungria M (2015) Co-inoculation of soybean with Bradyrhizobium and Azospirillum promotes early nodulation. Am J Plant Sci 6:1641-1649

Cooper JE (2007) Early interactions between legumes in rhizobia: disclosing complexity in a molecular dialogue. J Appl Microbiol 103:1355-1365

D'Haeze W, Holsters M (2002) Nod factors structures, responses, and perception during initiation of nodule development. Glycobiology 12:79-105

Dardanelli MS, de Córdoba FJF, Espuny MR, Carvajal MAR, Díaz MES, Serrano AMG, Okon Y, Megías M (2008) Effect of Azospirillum brasilense 
coinoculated with Rhizobium on Phaseolus vulgaris flavonoids and Nod Factor production under salt stress. Soil Biol Biochem 40:2713-2721

De Jong AJ, Heidstra R, Spaink HP, Hartog MV, Meijer EA, Hendriks T, Schiavo FL, Terzi M, Bisseling T, van Kammen A, de Vries SC (1993) A plant somatic embryo mutant is rescued by rhizobial lipo-oligossacharides. Plant Cell 5:615-620

de Rijke E, Out P, Niessen WMA, Ariese F, Gooijer C, Brikman UAT (2006) Analytical separation and detection methods for flavonoids. J Chromatogr 1112:31-63

Debellé F, Plazanet C, Roche P, Pujol C, Savagnac A, Rosenberg C, Promé J, Dénarié $J$ (2003) The NodA proteins of Rhizobium meliloti specify the $N$-acylation of nod factors by different fatty acids. Mol Microbiol 22:303-314

del Cerro P, Rolla-Santos AAP, Gomes DF, Marks BB, Espuny MR, RodriguezCarvajal MA, Soria-Diaz E, Nakatani AS, Hungria M, Ollero FJ, Megías M (2015a) Opening the "black box" of nodD3, nodD4 and nodD5 genes of Rhizobium tropici strain CIAT 899. BMC Genom. doi:10.1186/ s12864-015-2033-z)

del Cerro P, Rolla-Santos AAP, Gomes DF, Marks BB, Pérez-Montaño F, Rodríguez-Carvajal MA, Nakatani AS, Gil-Serrano A, Megías M, Ollero FJ, Hungria M (2015b) Regulatory nodD1 and nodD2 genes of Rhizobium tropici strain CIAT899 and their roles in the early stages of molecular signaling and host-legume nodulation. BMC Genom 16:251. doi:10.1186/ s12864-015-1458-8

Díaz-Zorita M, Fernandez-Canigia MV (2009) Field performance of a liquid formulation of Azospirillum brasilense on dryland wheat productivity. Eur J Soil Biol 45:3-11

Döbereiner J, Baldani VLD, Baldani JI (1995) Como isolar e identificar bactérias diazotróficas de plantas não-leguminosas. Embrapa-SPI, Itaguaí

Embrapa (2011) Cultivo do Milho_-Sistema de Produção, 1. Available at: http://www.cnpms.embrapa.br/publicacoes/milho_7_ed/index.htm. Accessed 10 May 2015

Estévez J, Soria-Díaz ME, de Córdoba FF, Morón B, Manyani H, Gil A, ThomasOates J, van Brussel AAN, Dardanelli MS, Sousa C, Megías M (2009) Different and new nod factors produced by Rhizobium tropici CIAT899 following $\mathrm{Na}^{+}$stress. FEMS Microbiol Lett 293:220-231

Folch-Mallol JL, Marroquí S, Sousa C, Manyani H, López-Lara IM, van der Drift KMGM, Haverkamp J, Quinto C, Gil-Serrano A, Thomas-Oates J, Spaink HP, Megías M (1996) Characterization of Rhizobium tropici CIAT 899 nodulation factors: the role of nodH and nodPQ genes in their sulfation. Mol Plant Microbe Interact 9:151-163

Fuentes-Ramirez LE, Caballero-Mellado J (2005) Bacterial biofertilizers. In: Sadiqui ZA (ed) PGPR: Biological control and biofertilization. Springer, Dordrecht, pp 143-172

Guasch-Vidal B (2011) Selección y caracterización de mutantes de Rhizobium tropici CIAT 899 afectados em la producción de factores Nod en condiciones de estrés salino. Tesis Doctoral, Universidad de Sevilla

Hameeda B, Rupela OP, Reddy G, Satyavani K (2006) Application of plant growth-promoting bacteria associated with composts and macrofauna for growth promotion of pearl millet (Pennisetum glaucum L.). Biol Fertil Soils 43:221-227

Hartmann A, Bashan Y (2009) Ecology and application of Azospirillum and other plant growth-promoting bacteria (PGPB). Eur J Soil Biol 45:1-2

Hungria M (2011) Inoculação com Azospirillum brasilense: inovação em rendimento a baixo custo. Embrapa Soja, Londrina. (Circular Técnica, 325). ISSN, 1516-781X

Hungria M, Araujo RS (1994) Manual de métodos empregados em estudos de microbiologia agrícola. EMBRAPA-SPI, Brasília, Brazil, p 542. (ISSN 0101-9716)

Hungria M, Mendes IC (2015) Nitrogen fixation with soybean: the perfect symbiosis? In: De Bruijn F (ed) Biological nitrogen fixation., v.2, chapter 99. Wiley, NJ, pp 1005-1019

Hungria M, Phillips DA (1993) Effects of a seed color mutation on rhizobial nod-gene-inducing flavonoids and nodulation in common bean. Mol Plant Microbe Interact 6:418-422

Hungria M, Johnston AWB, Phillips DA (1992) Effects of flavonoids released naturally from bean (Phaseolus vulgaris) on nodD-regulated gene transcription in Rhizobium leguminosarum bv. phaseoli. Mol Plant Microbe Interact 5:199-203

Hungria M, Campo RJ, Souza EM, Pedrosa FO (2010) Inoculation with selected strains of Azospirillum brasilense and A. lipoferum improves yield of maize and wheat in Brazil. Plant Soil 331:413-425
Hungria M, Nogueira MA, Araujo RS (2013) Co-inoculation of soybeans and common beans with rhizobia and azospirilla: strategies to improve sustainability. Biol Fertil Soils 49:791-801. doi:10.1007/s00374-012-0771-5

Hungria M, Nogueira MA, Araujo RS (2015a) Alternative methods and time for soybean inoculation to overcome adverse conditions at sowing. Afr J Agric Res 10:2329-2338

Hungria M, Nogueira MA, Araujo RS (2015b) Soybean seed co-inoculation with Bradyrhizobium spp. and Azospirillum brasilense: a new biotechnological tool to improve yield and sustainability. Am J Plant Sci 6:811-817

Khan W (2003) Plant responses to signaling compounds. Thesis, McGill University

Khan W, Prithiviraj B, Smith DL (2008) Nod Factor [Nod Bj V (C ${ }_{18: 1}$, MeFuc)] and lumichrome enhances photosynthesis and growth of corn and soybean. J Plant Physiol 165:1342-1351

Liang Y, Cao Y, Tanaka K, Thibivilliers S, Wan J, Choi J, Kang C, Qiu J, Stacey G (2013) Nonlegumes respond to rhizobial nod factors by suppressing the innate immune response. Science 341:1384-1387

MAPA (Ministério da Agricultura, Pecuária e Abastecimento). Anexo à IN SDA 13, de 24/03/2011. (2011) Requisitos mínimos para avaliação da viabilidade e eficiência agronômica de cepas, produtos e tecnologias relacionados à micro-organismos promotores de crescimento. Available at. <http://www.agricultura.gov.br/arq_editor/file/vegetal/RegistroAutorizacoes/Registro\%20de\%20Estabelecimento\%20e\%20Produto/ IN\%2013-2011\%20inocul\%20-\%20protocolo\%20-\%20microorg\%20 promotores\%20de\%20crescimento\%20-\%20alterado\%203-5-12.pdfs>. Accessed 13 July 2015

Marks BB, Megías M, Nogueira MA, Hungria M (2013) Biotechnological potencial of rhizobial metabolites to enhance the performance of Bradyrhizobium spp. and Azospirillum brasilense inoculants with soybean and maize. AMB Express 3:21. doi:10.1186/2191-0855-3-21

Massoud ON, Morsy EM, El-Batanony NH (2009) Field response of snap bean (Phaseolus vulgaris L.) to $\mathrm{N}_{2}$-fixers Bacillus circulans and arbuscular mycorrhizal fungi inoculation through accelerating rock phosphate and feldspar weathering. Aust J Basic Appl Sci 3:844-852

Miransari M, Smith D (2009) Rhizobial lipo-chitooligosaccharides and gibberellins enhance barley (Hordeum vulgare L.) seed germination. Biotechnology 8:270-275

Morón B, Soría-Díaz ME, Ault J, Verroios G, Noreen S, Rodríguez-Navarro DN, Gil-Serrano A, Thomas-Oates J, Megías M, Sousa C (2005) Low pH changes the profile of nodulation factors produced by Rhizobium tropici CIAT899. Chem Biol 12:1029-1040

Mulder L, Lefebvre B, Cullimore D, Imberty A (2006) LysM domains of Medicago truncatula NFP protein involved in Nod Factor perception, glycosylation state, molecular modeling and docking of chitooligosaccharides and Nod Factors. Glycobiology 16:801-809

Okon Y, Kapulnik Y (1986) Development and function of Azospirillum-inoculated roots. Plant Soil 90:3-16

Okon Y, Labandera-Gonzalez CA (1994) Agronomic applications of Azospirillum: an evaluation of 20 years worldwide field inoculation. Soil Biol Biochem 26:1591-1601

Olah B, Brière C, Bécard G, Dénarié J, Gough C (2005) Nod Factors and a diffusible factor from arbuscular mycorrhizal fungi stimulate lateral root formation in Medicago truncatula via the DMI1/DMI2 signalling pathway. Plant J 44:195-207

Ormeño-Orrillo E, Menna P, Almeida LGP, Ollero FJ, Nicolás MF, Rodrigues EP, Nakatami AS, Batista JSS, Chueire LMO, Souza RC, Vasconcelos ATR, Megías M, Hungria M, Martínez-Romero E (2012) Genomic basis of broad host range and environmental adaptability of Rhizobium tropici CIAT899 and Rhizobium sp. PRF81 which are used in inoculants for common bean (Phaseolus vulgaris L.). BMC Genom 13:735

Phillips DA (2000) Biosynthesis and release of rhizobial nodulation gene inducers by legumes. In: Triplett (ed) Prokariotic nitrogen fixation: a model system for the analysis of a biological process. Horizon Scientific Press, Wymondham, pp 349-364

Prithiviraj B, Zhou X, Souleimanov A, Kahn WM, Smith DL (2003) A host-specific bacteria-to-plant signal molecule (Nod Factor) enhances germination and early growth of diverse crop plants. Planta 216:437-445

Rélic B, Talmont F, Korsinska J, Golinowski W, Prome JC, Broughton WJ (1993) Biological activity of Rhizobium sp. NGR234 Nod Factors on Macroptillium atropurpureum. Mol Plant Microbe Interact 6:764-774 
Riely BK, Ané JM, Penmetsa RV, Cook DR (2004) Genetic and genomic analysis in model legumes bring Nod-Factor signaling to center stage. Curr Opin Plant Biol 7:408-413

Rodrigues EP, Rodrigues LS, Oliveira ALM, Baldani VLD, Teixeira KRS, Urquiaga S, Reis VM (2008) Azospirillum amazonense inoculation: effects on growth, yield and $\mathrm{N}_{2}$ fixation of rice (Oriza sativa L.). Plant Soil 302:249-261

Rodriguez H, Gonzalez T, Goire I, Bashan Y (2004) Gluconic acid production and phosphate solubilization by the plant growth-promoting bacterium Azospirillum ssp. Naturwissenschaften 91:552-555

Sanjuan J, Carlson RW, Spaink HP, Bhat UR, Barbour WM, Glushka J, Stacey G (1992) A 2-O-methylfucose moiety is present in the lipo-oligosaccharide nodulation signal of Bradyrhizobium japonicum. Proc Natl Acad Sci 89:8789-8793

Smith S, Habib A, Kang Y, Legget M, Díaz-Zorita M (2015) LCO applications provide improved responses with legumes and nonlegumes. In: de Bruijn F (ed) Biological nitrogen fixation, v.2, chapter 107. John Wiley \& Sons, Inc, Hoboken, NJ, USA, pp 1077-1086. doi:10.1002/9781119053095.ch107

Soria-Díaz ME, Tejero-Mateo P, Espartero JL, Rodríguez-Carvajal MA, Morón B, Sousa C, Megías M, Amarger M, Thomas-Oates J, Gil-Serrano AM (2003) Structural determination of the lipo-chitin oligosaccharide nodulation signal produced by Rhizobium giardinii H152. Carbohydr Res 338:237-250

Souleimanov A, Prithiviraj B, Smith DL (2002) The major Nod Factor of Bradyrhizobium japonicum promotes early growth of soybean and corn. J Exp Bot 53:1929-1934
Spaink H, Kondorosi A, Hooykaas PJJ (1998) The Rhizobiaceae: molecular biology of model plant-associated bacteria. Kluwer Academia Publishers, Dordrecht

Staehelin C, Granado J, Muller J, Wiemeken A, Mellor RB, Felix G, Regenass M, Broughton WJ, Boller T (1994) Perception of Rhizobium nodulation factor by tomato cells and inactivation by roots chitinases. Proc Natl Acad Sci USA 91:2196-2200

Strzelczyk E, Kamper M, Li C (1994) Cytocinin-like-substances and ethylene production by Azospirillum in media with different carbon sources. Microbiol Res 149:55-60

Tien TM, Gaskins MH, Hubbel DH (1979) Plant growth substances produced by Azospirillum brasilense and their effect on the growth of pearl millet (Pennisetum americanum L.). Appl Environ Microbiol 37:1016-1024

Wang E, Huijun W, Junqing Q, Jun L, Yanfei X, Xuewen G (2009) Molecular mechanism of plant growth promoting and induced systemic resistance to tobacco mosaic virus by Bacillus spp. J Microbiol Biotechnol 19:1250-1258

Zawonski MS, Ameneiros M, Benavides MP, Vázquez S, Groppa MD (2011) Response to saline stress and aquaporin expression in Azospirillum-inoculated barley seedlings. Appl Microbiol Biotechnol 90:1389-1397

\section{Submit your manuscript to a SpringerOpen ${ }^{\odot}$ journal and benefit from:}

- Convenient online submission

- Rigorous peer review

- Immediate publication on acceptance

- Open access: articles freely available online

- High visibility within the field

- Retaining the copyright to your article

Submit your next manuscript at $>$ springeropen.com 